Penelitian

\title{
Respons dan Karakteristik Estrus setelah Sinkronisasi Estrus dengan Cloprostenol pada Sapi Friesian Holstein
}

\author{
(Response and Characteristics of Estrous after Estrous Synchronization with Cloprostenol \\ In Friesian Holstein (ow)
}

\author{
Musthamin Balumbi', Iman Supriatna², Mohamad Agus Setiadi ${ }^{2 *}$ \\ 'Program Studi Biologi Reproduksi, Sekolah Pascasarjana Institut Pertanian Bogor \\ ${ }^{2}$ Divisi Reproduksi dan Kebidanan, Departemen Klinik, Reproduksi, dan Patologi, \\ Fakultas Kedoteran Hewan,Institut Pertanian Bogor,Jl. Agatis Kampus IPB Dramaga Bogor, 16880 Bogor \\ *Penulis untuk korespondensi: setiadio3@yahoo.com \\ Diterima 3 Juni 2018, Disetujui 15 Oktober 2018
}

\begin{abstract}
ABSTRAK
Penelitian tentang sinkronisasi estrus pada sapi perah Friesian Holstein (FH) menggunakan cloprostenol telah dilakukan. Penelitian ini bertujuan untuk mengamati respons dan karakteristik estrus serta pengukuran nilai hambatan arus listrik lendir vagina. Penelitian dilakukan pada 20 ekor sapi FH dengan dua perlakuan injeksi cloprostenol, yaitu injeksi tunggal dengan keberadaan corpus luteum dan injeksi ganda dengan selang waktu injeksi 11 hari. Pengamatan estrus dan pengukuran lendir dilakukan lima hari berturut-turut setelah injeksi cloprostenol yang terakhir. Parameter pengukuran yang diamati meliputi respons, onset, dan durasi estrus, serta nilai hambatan arus listrik lendir vagina. Hasil penelitian menunjukkan bahwa injeksi ganda menghasilkan respons estrus yang lebih baik dibandingkan injeksi tunggal ( $90 \%$ vs $70 \%$ ), dengan onset estrus lebih pendek (47,55 jam vs 53,28 jam), dan durasi estrus lebih pendek (24,85 jam vs 23,55 jam). Data hambatan arus listrik lendir vagina pada kelompok injeksi ganda lebih rendah dibandingkan dengan injeksi tunggal $(187,77$ vs 192,14), dengan pola tinggi sebelum estrus, rendah pada saat estrus, dan tinggi kembali setelah estrus, baik pada kelompok injeksi tunggal maupun injeksi ganda. Dapat disimpulkan bahwa respons estrus pada kelompok injeksi ganda lebih baik dibandingkan dengan kelompok injeksi tunggal.
\end{abstract}

Kata kunci: cloprostenol, estrus, lendir, resistansi, sinkronisasi

\begin{abstract}
Research on estrous synchronization in Friesian Holstein $(\mathrm{FH})$ dairy cows using cloprostenol was conducted. This study aimed to observe the response and estrous characteristics as well as electrical resistance measurement of vaginal mucus. Synchronization treatments were conducted with two different cloprostenol injection frequencies using $20 \mathrm{FH}$ cows, namely single injection based on the presence of corpus luteum and double injections with 11 days interval. Estrous detection and electrical resistance measurement of vaginal mucus were performed for five consecutive days after the last injection of cloprostenol. Observation was conducted on response, onset, and estimated duration of estrous, as well as electrical resistance of vaginal mucus. The results of the experiment revealed that double injections of cloprostenol resulted in a better estrous response than single injection ( $90 \%$ vs $70 \%$ ), with a shorter onset of estrous ( 47,55 hours vs 53,28 hours), and shorter estimated duration of estrous ( 23,55 hours vs 24,85 hours). Furthermore, data on electrical resistance of vaginal mucus was lower in the double injections compared to the single injection treatment $(187,77$ vs 192,14), with consistent pattern of high before estrous, low during estrous, and increase after estrous either in single injection or double injections treatment. It is concluded that response of estrous in double injection treatment is better synchronized than in single injection treatment.
\end{abstract}

Keywords: cloprostenol, estrous, mucus, resistance, synchronization 


\section{PENDAHULUAN}

Sinkronisasi estrus merupakan usaha untuk menyeragamkan terjadinya gejala estrus dan ovulasi pada ternak dengan memanipulasi organ reproduksi betina menggunakan preparat hormon. Prinsip sinkronisasi estrus adalah memerpanjang atau memerpendek masa hidup corpus luteum $(\mathrm{CL})$ atau fase luteal (Hafez \& Hafez, 2000). Salah satu metode sinkronisasi estrus dengan memerpendek fase luteal biasanya menggunakan sediaan hormon prostaglandin $\left(\mathrm{PGF}_{2 \alpha}\right)$ dengan melisiskan $\mathrm{CL}$ sehingga estrus kembali terjadi (Whitley \& Jackson, 2004). Stotzel et al. (2012) melaporkan bahwa pemberian $\mathrm{PGF}_{2 a}$ pada pertengahan fase luteal menyebabkan luteolisis dalam beberapa jam sehingga konsentrasi progesteron $\left(\mathrm{P}_{4}\right)$ menurun dan kadar estrogen $\left(\mathrm{E}_{2}\right)$ meningkat yang akan merangsang hipofisis anterior melepaskan follicle stimulating hormone (FSH) dan luteinizing hormone (LH), yang menyebabkan perkembangan dan pematangan folikel sehingga menyebabkan terjadinya estrus dan ovulasi.

Terdapat berbagai macam sediaan hormon $\mathrm{PGF}_{2 a}$ yang ada di pasaran dengan berbagai macam zat aktif, seperti luprostiol, tiaprost, dinoprost, fenprostale, dan cloprostenol. Dosis yang diperlukan untuk induksi terjadinya estrus pada sapi bermacam-macam, seperti $15-30 \mathrm{ml}$ (15000-30000 $\mu \mathrm{g})$ luprostiol (Plata et al., 1989), $5 \mathrm{ml}(2500 \mu \mathrm{g})$ tiaprost (iliren) (Dekaet al.,2009), $25 \mathrm{ml}(25000 \mu \mathrm{g})$ dinoprost (Gatius \& Urgel, 1989), dan $2 \mathrm{ml}(1000 \mu \mathrm{g})$ fenprostale (Davis et al.,1984). Dari berbagai macam sediaan tersebut hanya cloprostenol yang memiliki dosis paling sedikit dibandingkan dengan yang lainnya. Dengan $500 \mu \mathrm{g}$ cloprostenol sudah dapat menimbulkan estrus dengan baik dan tidak memiliki efek samping pada ternak sapi (Lauderdale, 2005). Lebih lanjut, Stevenson \& Phatak (2010) melaporkan bahwa mekanisme kerja cloprostenol sama dengan hormon $\mathrm{PGF}_{2 a}$ endogen, yang akan berikatan dengan reseptor $\mathrm{PGF}_{2 \alpha}$ pada $\mathrm{CL}$ sehingga mengakibatkan luteolisis.

Aplikasi induksi estrus menggunakan $\mathrm{PGF}_{2 a}$ biasanya dilakukan dengan dua cara, yaitu injeksi tunggal (single injection) dan injeksi ganda (double injection). Metode injeksi tunggal biasanya efektif untuk menyeragamkan estrus ternak jika siklus estrusnya diketahui telah berada dalam fase luteal dengan CL fungsional (Nascimento et al., 2014), sedangkan metode injeksi ganda dapat diaplikasikan baik pada fase folikuler maupun fase luteal (Hafez \& Hafez, 2000). Tingkat keberhasilan dalam menyeragamkan estrus lebih tinggi pada metode injeksi ganda dibandingkan injeksi tunggal (Archbald et al.,
1993; Stephen \& Rajamadheran, 1998; Martins et al., 2011), dan lebih cepat menurunkan kadar $\mathrm{P}_{4}$ dan menginduksi terjadinya luteolisis (Nascimentoet al., 2014).

Kualitas estrus yang baik biasanya dicirikan dengan dihasilkannya folikel besar yang bagus dan dihasilkannya estrogen yang tinggi sehingga berimplikasi menimbulkan tanda-tanda estrus yang jelas. Salah satu tanda estrus yang menonjol biasanya dihasilkannya sejumlah lendir yang jernih. Menurut Setiadi dan Aepul (2010) untuk mendapatkan kualitas estrus yang baik dalam sinkronisasi estrus dapat dilihat pada ciri khusus yang timbul, seperti produksi lendir vagina. Lendir vagina yang berlebihan pada saat estrus sering dijadikan patokan dalam menentukan status estrus. Oleh karena itu, dilakukanlah penelitian mengenai respons dan karakteristik estrus setelah sinkronisasi estrus dengan injeksi cloprostenol pada sapi Friesian Holstein.

Untuk memperoleh keberhasilan sinkronisasi dan polanya maka dilakukan penelitian melalui berbagai teknik aplikasi sinkronisasi estrus menggunakan cloprostenol sebagai stimulasi induksi luteolisis dengan dosis yang paling rendah dengan pengamatan respons dan karakteristik estrus yang meliputi onset, durasi, dan pengukuran hambatan arus listrik lendir estrus.

\section{BAHAN DAN METODE}

\section{Seleksi dan Pemilihan Hewan Coba}

Seleksi dan pemilihan hewan penelitian dilakukan melalui pemeriksaan secara fisik, yaitu palpasi per rektal untuk memastikan status reproduksinya. Hewan yang dipilih merupakan hewan sehat, tidak bunting, dan minimal telah satu kali beranak.

\section{Perlakuan Sinkronisasi dengan Cloprostenol}

Sebanyak 20 ekor sapi $\mathrm{FH}$ dibagi menjadi 2 kelompok, yaitu 10 ekor disinkronisasi dengan injeksi tunggal dan 10 ekor dengan injeksi ganda prostaglandin (cloprostenol). Dosis injeksi prostaglandin yang digunakan adalah $2 \mathrm{ml}(500 \mu \mathrm{g})$ cloprostenol secara intramuskuler per injeksi. Kelompok injeksi tunggal dilakukan hanya pada hewan yang memiliki $\mathrm{CL}$ yang fungsional pada ovariumnya berdasarkan palpasi per rektal, sedang-kan kelompok injeksi ganda tidak memerhatikan status reproduksi, baik berada pada fase folikuler maupun luteal. Injeksi cloprostenol dilakukan dengan selang waktu 11 hari dari injeksi pertama (Hafez \& Hafez, 2000). Perla- 
kuan injeksi tunggal dan injeksi ganda disajikan pada Gambar 1 dan Gambar 2.

\section{Pengamatan Estrus}

Pengamatan estrus dilakukan satu kali sehari selama lima hari berturut-turut setelah injeksi $\mathrm{PGF}_{2 a}$ yang terakhir dengan mengamati gejala estrus dan pengukuran hambatan arus listrik lendir vagina.

\section{Pengukuran Daya Hambat Arus Listrik (Resistansi) Lendir Vagina}

Pengukuran daya hambat arus listrik (resistansi) lendir vagina dilakukan dengan menggunakan alat Draminski ${ }^{\oplus}$ Estrous Detector. Alat ini terdiri atas probe yang pada ujungnya terdapat dua elektroda paralel satu dengan lainnya untuk mengukur nilai hambatan arus listrik lendir vagina. Selain itu, terdapat bagian elektronik yang dilengkapi layar untuk pembacaan hasil, serta handle yang dilengkapi baterai standar 9 volt. Pengamatan dilakukan dengan memasukkan probe sekitar $30-40 \mathrm{~cm}$ dari vulva, kemudian menekan tombol sampai angka pada layar menunjukkan angka yang stabil. Skala pengukuran dinyatakan dengan angka kisaran 0-1990. Prinsip pengukuran nilai hambatan arus listrik lendir vagina dengan menggunakan detektor ini adalah bahwa voltase yang dialirkan melalui dinding vagina sebagai respons aliran arus listrik pada frekuensi tertentu sehingga dapat dihitung dengan persamaan $\mathrm{V}=\mathrm{IR}$, dimana $\mathrm{V}$ adalah voltase yang di- alirkan ke dalam dinding vagina, I adalah arus yang dialirkan dan $\mathrm{R}$ adalah tahanan dari bagian yang diukur sebagai respons aliran arus yang diberikan (Rezac et al., 2001).

Data yang diperoleh dari pengukuran estrus detektor dikonfirmasi dengan gejala estrus yang teramati dan dibuat tabulasi. Tanda-tanda sapi yang mengalami estrus ditunjukkan dengan tingkah laku sapi, seperti sapi yang terlihat gelisah, sering menguak-nguak, dan terkadang berusaha menaiki betina di sebelahnya. Selain itu, dilakukan juga konfirmasi dengan palpasi per rektal untuk mengamati ketegangan uterus dan keberadaan folikel yang berkembang.

\section{Parameter Pengukuran Penelitian}

Parameter pengukuran penelitian meliputi:

1. Persentase sapi yang mengalami estrus: adalah jumlah sapi yang menunjukkan gejala estrus dibagi dengan semua betina yang diberi perlakuan dikali 100.

2. Onset estrus: adalah interval (jarak) dari injeksi cloprostenol yang terakhir sampai timbulnya gejala estrus pertama.

3. Perkiraan durasi estrus: adalah interval (jarak) dari waktu pertama kali timbulnya estrus sampai perkiraan gejala estrus berakhir.

4. Resistansi: adalah nilai hambatan arus listrik yang terekam dan dikonversi dalam angka dari alat.

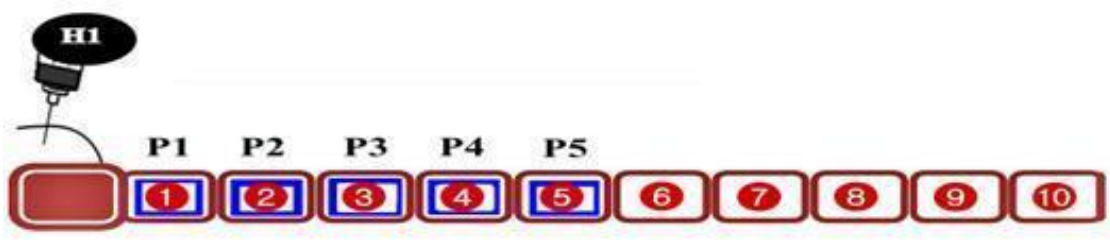

Gambar 1 Skema injeksi tunggal cloprostenol secara intramuskuler. H1 adalah waktu dilakukannya injeksi, P1-P5 adalah waktu pengamatan gejala estrus

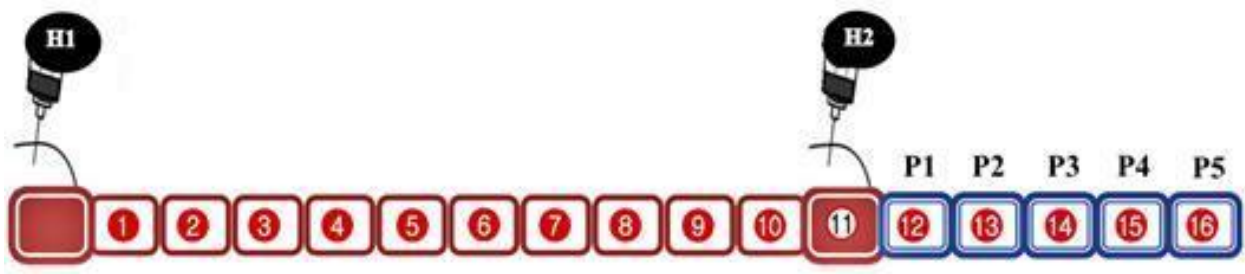

Gambar 2 Skema injeksi ganda cloprostenol secara intramuskuler.H1 adalah waktu dilakukannya injeksi pertama, $\mathrm{H} 2$ adalah waktu injeksi kedua.P1-P5 adalah waktu pengamatan gejala estrus 
32 | Balumbi et al.

\section{Analisis Data}

Persentase sapi yang mengalami estrus diuji proporsinya menggunakan Microsoft Excel ${ }^{\oplus} 2010$. Data onset estrus, durasi estrus, dan resistansi lendir vagina ditabulasikan kemudian diuji dengan independent $t$-test.

\section{HASIL}

\section{Respons dan Karakteristik Estrus}

Hasil penelitian menunjukkan jumlah sapi yang berespons terhadap sinkronisasi estrus dengan injeksi ganda memerlihatkan 90\% sapi perlakuan menunjukkan gejala estrus, dibandingkan dengan hasil sinkronisasi dengan injeksi tunggal yang hanya mencapai 70\% (Tabel 1). Selain itu, waktu timbulnya estrus baik pada penyuntikan ganda maupun pada penyuntikan tunggal tidak menunjukkan perbedaan yang nyata $(P>0,05)$. Namun demikian, terdapat perbedaan yang nyata pada perkiraan durasi estrus $(P<0,05)$ (Tabel 1).

\section{Daya Hambat Arus Listrik (Resistansi) Lendir Vagina}

Nilai hasil pengukuran daya hambat arus listrik lendir estrus pada sapi setelah perlakuan sinkronisasi baik injeksi tunggal maupun injeksi ganda terlihat pada Gambar 3 dan 4. Data daya hambat arus listrik memperlihatkan pola tinggi sebelum estrus, rendah pada saat estrus, dan tinggi kembali setelah estrus, baik pada sapi yang diinjeksi ganda (Gambar 3) maupun yang diinjeksi tunggal (Gambar 4).

\section{PEMBAHASAN}

\section{Respons dan Karakteristik Estrus}

Hasil penelitian sinkronisasi estrus menggunakan cloprostenol dengan injeksi tunggal hanya menghasilkan $70 \%$ sapi perlakuan yang menunjukkan gejala estrus. Sementara itu, perlakuan dengan injeksi ganda menghasilkan respons estrus yang mencapai 90\%. Data ini menunjukkan perlakuan injeksi ganda menghasilkan respons estrus yang lebih baik. Hasil penelitian ini sejalan dengan hasil yang dilaporkan oleh Ribeiro et al. (2012) pada sapi $\mathrm{FH}$, dengan persentase estrus akibat luteolisis pada injeksi tunggal sebesar $61,7 \%$, sedangkan pada injeksi ganda sebesar $96,2 \%$. Lebih lanjut hasil penelitian Ribeiro et al. (2012) juga menunjukkan perlakuan injeksi ganda dinoprost sebagai $\mathrm{PGF}_{2 a}$ alami menghasilkan respons estrus yang lebih baik dibandingkan dengan injeksi tunggal ( $95,7 \%$ vs $82 \%$ ). Dari berbagai penelitian tersebut di atas menunjukkan bahwa respons estrus yang terjadi akibat injeksi ganda menghasilkan angka respons yang lebih baik dibandingkan dengan injeksi tunggal. Lebih lanjut hasil penelitian Martins et al. (2011), baik menggunakan PGF2a alami (dinoprost) maupun $\mathrm{PGF}_{2 \alpha}$ analog (cloprostenol) pada sapi $\mathrm{FH}$ dengan injeksi ganda menghasilkan respons estrus yang lebih baik ( $91 \%$ dan 94\%).

Tingginya proporsi estrus pada injeksi ganda kemungkinan disebabkan oleh keseragaman umur $\mathrm{CL}$ yang fungsional pada penyuntikan kedua (Ribeiro et al., 2012) sehingga menghasilkan respons estrus yang tinggi dan seragam dibandingkan dengan injeksi tunggal. Lebih lanjut Junior et al. (2016) melaporkan bahwa injeksi ganda $\mathrm{PGF}_{2 a}$ pada aplikasi sinkronisasi estrus sapi dapat dengan baik melisiskan $\mathrm{CL}$ sehingga kadar $\mathrm{P}_{4}$ akan serentak menurun sehingga estrus akan terjadi secara serentak. Lisisnya $\mathrm{CL}$ akan menginduksi terjadinya estrus (Torres et al., 2013; Hassan et al., 2016). Pada perlakuan injeksi tunggal kemungkinan didapatkan umur $\mathrm{CL}$ yang bervariasi sehingga menghasilkan estrus yang tidak seragam dan kemungkinan tidak berespons apabila tidak dapat dipastikan umur CL-nya. Selain itu, hal lain yang memengaruhi respons estrus yang tinggi pada injeksi ganda adalah faktor individu yang berbeda pada setiap perlakuan (Hafez \& Hafez, 2000; Hassan et al., 2016).

Tidak beresponsnya sapi perlakuan kemungkinan disebabkan oleh perbedaan diameter CL. Corpus luteum yang berdiameter kecil umumnya belum matang dan fungsional. Corpus luteum yang belum matang tidak memiliki reseptor $\mathrm{PGF}_{2 a}$ sehingga induksi luteolisis dengan $\mathrm{PGF}_{2 a}$ pada fase ini akan mengalami kegagalan (Hafez \& Hafez, 2000; Lemaster et al., 2001). Lebih lanjut diketahui bahwa

Tabel 1 Pengaruh pemberian cloprostenol pada proporsi respons, onset, dan durasi estrus

\begin{tabular}{cccc}
\hline Perlakuan & Proporsi respons estrus $(n=10)$ & $\begin{array}{c}\text { Rataan onset } \\
\text { estrus (jam) }\end{array}$ & $\begin{array}{c}\text { Rataan perkiraan } \\
\text { durasi estrus (jam) }\end{array}$ \\
\hline Injeksi tunggal & $70 \%$ & $53,28 \pm 11,17$ & $24,85 \pm 1,06^{\text {a }}$ \\
Injeksi ganda & $90 \%$ & $47,55 \pm 11,50$ & $23,55 \pm 0,52^{\mathrm{b}}$ \\
\hline
\end{tabular}

Angka yang diikuti huruf dengan superscript yang berbeda pada kolom yang sama menunjukkan perbedaan nyata $(P<0,05)$ 


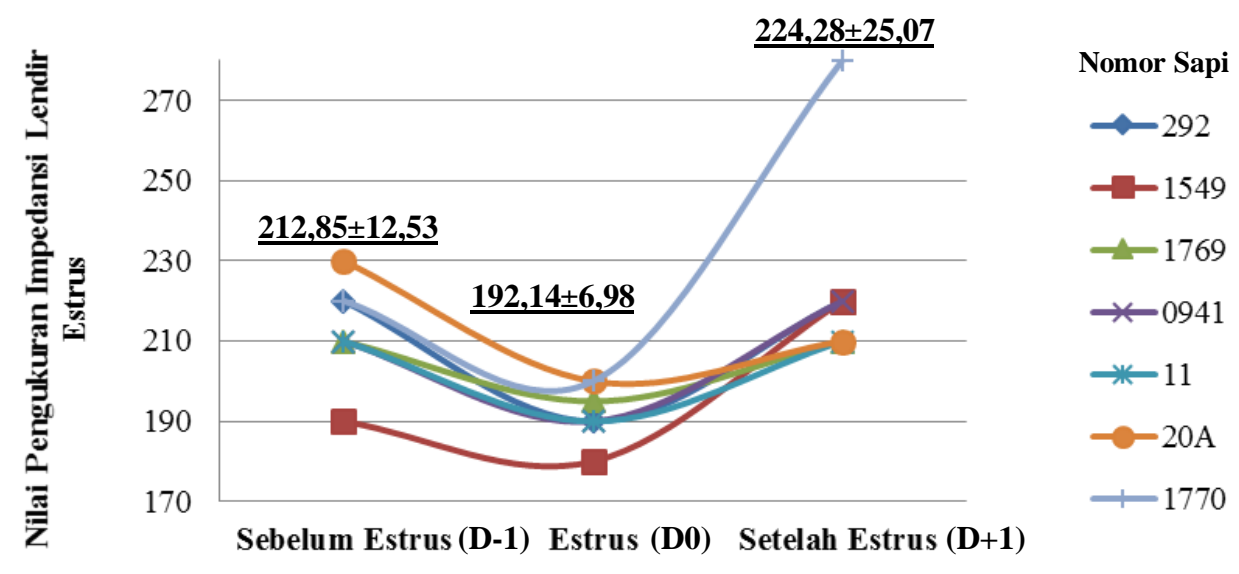

Gambar 3 Nilai hambatan arus listrik hasil sinkronisasi estrus injeksi tunggal dengan cloprostenol

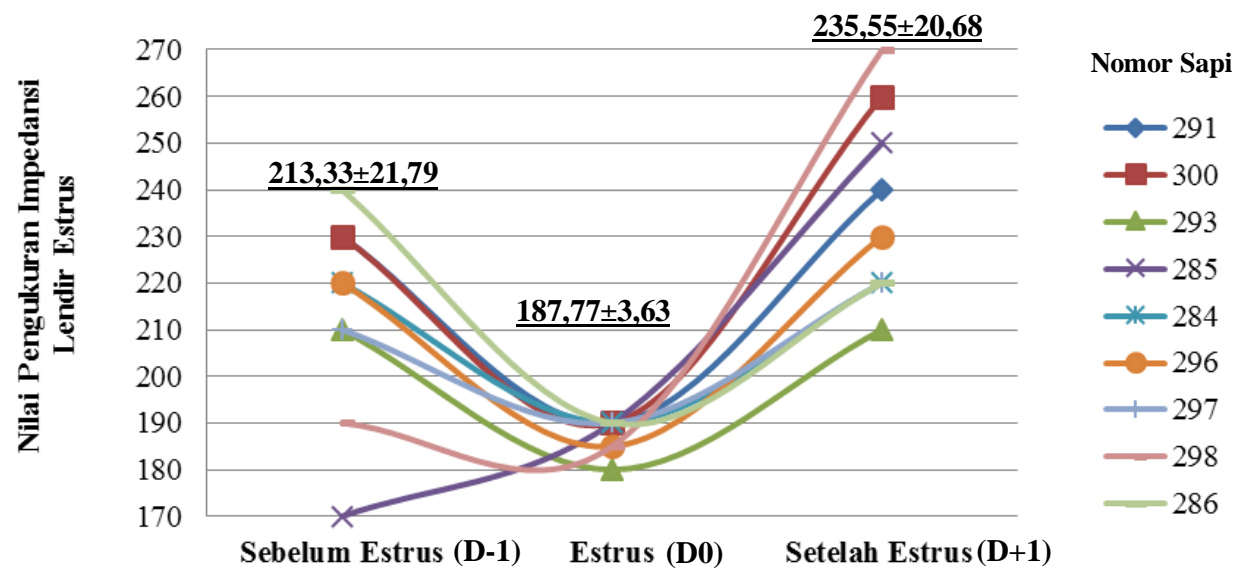

Gambar 4 Nilai hambatan arus listrik hasil sinkronisasi estrus injeksi ganda dengan cloprostenol

$\mathrm{PGF}_{2 a}$ hanya efektif bila ada $\mathrm{CL}$ fungsional, yaitu antara hari ke-7 sampai hari ke-18 siklus estrus (Hafez \& Hafez,2000).

Regresi $\mathrm{CL}$ berbanding lurus dengan penurunan produksi $\mathrm{P}_{4}$. Corpus luteum yang berukuran besar menghasilkan konsentrasi $\mathrm{P}_{4}$ yang tinggi (Uslenghi et al., 2016). Penurunan $\mathrm{P}_{4}$ dan perkembangan folikel ovarium memengaruhi keberhasilan sinkronisasi estrus. Penurunan $\mathrm{P}_{4}$ menyebabkan hilangnya feedback (umpan balik) negatif ke hipofisis anterior sehingga hipofisis anterior akan mensekresikan follicle stimulating hormone (FSH) dan luteinizing hormone (LH). Sekresi FSH akan menstimulasi perkembangan folikel dan peningkatan sekresi estrogen sehingga terjadilah estrus (Salverson \& Perry, 2007). Penurunan konsentrasi $\mathrm{P}_{4}$ oleh $\mathrm{PGF}_{2 a}$ juga disebabkan oleh adanya mekanisme aktivasi protein kinase (PKC) yang menghambat konversi kolesterol menjadi $\mathrm{P}_{4}$. Lebih lanjut dikemukakan oleh Waldmann et al. (2006) bahwa konsentrasi progesteron $5 \mathrm{ngmL}^{-1} \mathrm{pa}$ - da setiap pemberian $25 \mathrm{mg} \mathrm{PGF}_{2 a}$ akan menurun $<2,5$ $\mathrm{ngmL}^{-1}$ setelah $72 \mathrm{jam}$.

Tingginya respons estrus pada injeksi ganda ditunjukkan pula dengan relatif pendeknya jarak injeksi terakhir dengan waktu timbulnya estrus. Onset estrus pada injeksi ganda relatif lebih pendek dan seragam dibandingkan dengan pada injeksi tunggal (47,55 jam dan 53,28 jam). Hasil ini sesuai dengan hasil penelitian Larson et al. (2006) yang menyatakan bahwa keserentakan estrus dapat terjadi dalam kurun waktu 2 atau 3 hari setelah perlakuan dengan preparat hormon $\mathrm{PGF}_{2 a}$. Hasil penelitian ini juga diperkuat oleh Yoshida et al. (2009) bahwa onset estrus setelah perlakuan dengan cloprostenol pada sapi FH adalah 44,4 $\pm 8,4$ jam.

Keseragaman onset estrus pada kelompok perlakuan injeksi ganda yang ditandai dengan lebih pendeknya rataan onset estrus, kemungkinan disebabkan oleh $\mathrm{CL}$ fungsional yang relatif berumur sama pada penyuntikan kedua (Ribeiro et al., 2012). 
Sementara itu, bervariasinya onset estrus pada injeksi tunggal ditunjukkan dengan lebih lamanya terjadinya onset estrus (53,28 jam). Hal ini kemungkinan disebabkan umur $\mathrm{CL}$ yang sangat bervariasi di antara individu sapi (Hafez \& Hafez, 2000), bahkan bisa saja berasal dari $\mathrm{CL}$ persisten yang bertahan lebih lama.

Hasil penelitian menunjukkan perkiraan durasi estrus pada kelompok perlakuan injeksi ganda berkisar 23,55 jam, yang lebih pendek dibandingkan dengan hasil penyerentakan dengan injeksi tunggal $(24,85$ jam). Data perkiraan durasi estrus ini masih sejalan dengan laporan Hafez \& Hafez (2000) bahwa durasi estrus pada sapi berkisar 12-30 jam, namun lebih panjang bila dibandingkan dengan laporan Rodtian et al. (1996) yang menyatakan bahwa durasi estrus pada sapi FH sekitar 18 jam.

Kekurangakuratan data perkiraan durasi estrus kemungkinan karena hanya dilakukan pengamatan penampakan gejala estrus tanpa pengamatan berdasarkan tanda-tanda estrus lainnya. Lama perkiraan durasi estrus juga dipengaruhi oleh iklim dan nutrisi (Gwazdauskas, 1985). Di samping itu, takaran nutrisi yang mengandung protein tinggi menghasilkan kadar estrogen yang lama beredar di dalam darah (Gwazdauskas, 1985) sehingga memperlama munculnya tanda estrus. Namun demikian, kisaran lama durasi estrus juga bergantung pada tiap individu sapi (Hafez \& Hafez,2000).

\section{Daya Hambat Arus Listrik (Resistansi) Lendir Vagina}

Hasil pengukuran nilai hambatan arus listrik yang dikonfirmasi dengan kemunculan tanda-tanda estrus secara umum memerlihatkan pola rataan nilai hambatan arus listrik yang tinggi sebelum estrus, menurun saat estrus, dan naik kembali setelah estrus pada Gambar 3 dan 4. Pola hambatan arus listrik seperti tersebut di atas juga telah dilaporkan pada domba garut (Setiadi \& Aepul, 2010), dan pada kambing PE (Setiadi etal., 2014)

Data penelitian menunjukkan bahwa pada saat estrus, kisaran nilai hambatan arus listrik pada kedua kelompok perlakuan berkisar antara 187,77 sampai dengan 192,14. Sementara itu, nilai kisaran hambatan arus listrik sebelum estrus berkisar antara 212,85 sampai dengan 213,33 , dan nilai hambatan arus listrik setelah estrus berkisar mulai dari 224,28 sampai dengan 235,55 . Pola yang demikian sejalan dengan hasil penelitian Patil\&Pawshe (2011) menggunakan Draminski ${ }^{\oplus}$ Estrous Detector dengan nilai hambatan arus listrik tinggi sebelum estrus (295), me- nurun saat estrus (230), dan meningkat lagi setelah estrus (262).

Nilai hambatan arus listrik pada saat estrus pada kelompok injeksi ganda lebih rendah $(187,77)$ dibandingkan dengan kelompok injeksi tunggal $(192,14)$. Rendahnya hambatan arus listrik dipengaruhi oleh perubahan komposisi lendir vagina (Setiadi \& Aepul 2010). Komposisi lendir vagina terdiri atas protein, lemak, kolestrol, sorbitol, gula reduksi, natrium, kalium, kalsium, fosfor organik, dan klorida (Zaaijer etal., 1992; Tsiligianni et al., 2000). Komposisi natrium, kalium, dan kalsium yang mengandung ion-ion, lebih banyak pada lendir kelompok injeksi ganda. Ion-ion ini bersifat elektrolit dan memiliki konduktivitas yang relatif tinggi sehingga semakin banyak jumlah dan volume ion-ion di lendir maka daya hambatan listrik juga rendah (Tsiligianni etal., 2000; Patil \& Pawshe, 2011; Verma et al., 2014).

Lendir serviks terbentuk dalam dua fase, yakni fase cairan dan kemudian fase gel. Fase cair mengandung sebagian besar air (92-95\%) dengan ion-ion dan metabolit, sedangkan fase gel mengandung glikoprotein (musin) (Kumaret al., 2012; Verma et al., 2014). Lendir yang bening pada saat estrus berbanding lurus dengan resistansi yang rendah. Hambatan listrik tertinggi terjadi pada fase luteal, sedangkan terendah adalah pada fase folikuler. Konduktivitas (ukuran suatu benda untuk menghantarkan listrik) jaringan vagina meningkat selama estrus (Lewis et al., 1989; Schindler et al., 1990).

Rendahnya nilai hambatan arus listrik pada saat estrus kemungkinan terjadi akibat peningkatan estrogen yang menyebabkan terjadinya hidrasi jaringan vulva yang dapat meningkatkan cairan ekstraseluler pada vulva (edematous) pada sapi perah (Lewis et al., 1989; Schindler et al., 1990). Lebih lanjut dilaporkan oleh Patil dan Pawshe (2011), Verma et al. (2014), dan Layek et al. (2013) bahwa hambatan listrik (resistansi) pada perubahan lendir vagina yang rendah pada fase estrus terjadi karena estrogen tinggi menyebabkan vasodilatasi pada vagina sehingga terjadi peningkatan jumlah dan volume ion-ion yang disekresikan oleh vagina. Ionion ini bersifat elektrolit dan memiliki konduktivitas yang relatif tinggi sehingga semakin banyak ion maka daya hambatan listrik juga semakin rendah.

Kesimpulan penelitian adalah bahwa injeksi ganda cloprostenol secara intramuskuler pada sapi FH menghasilkan respons estrus yang lebih baik. Nilai rataan hambatan arus listrik pada sapi FH saat estrus setelah sinkronisasi dengan cloprostenol ber- 
kisar antara 187,77 sampai dengan 192,14, dengan pola hambatan arus listrik lendir vagina menunjukkan tinggi sebelum estrus, kemudian menurun saat estrus, dan meningkat lagi setelah estrus.

\section{UCAPAN TERIMA KASIH}

Penulis mengucapkan terima kasih kepada PT. Gema Satwa Medika yang telah mendonasikan preparat hormon sebagai bahan penelitian.

"Penulis menyatakan tidak ada konflik kepentingan dengan pihak-pihak yang terkait dalam penelitian ini"

\section{DAFTAR PUSTAKA}

Archbald LF, Risco F, Chavatte P, Constant, Tran T, Klapstein E, Elliot. 1993. Estrus and pregnancy rate of dairy cows given one or two doses of prostaglandin F2 alpha 8 or 24 hours apart. Theriogenology. 40: 873-884.

Davis IF, McPhee SR, Clarke IJ. 1984. Efficacy of a prostaglandin $\mathrm{F} 2 \mathrm{a}$ analogue or PRID for synchronization of oestrus in dairy cows. Proceedings of the Australian Society of Animal Production. 15: 313-316.

Deka I, Goswami J, Chakraborty P, Biswas RK, Sarmah BK, Sarmah BC. 2009. Effect of iliren and norgestomet on synchronization of oestrus in cows. Indian Journal Animal. 43: 293-294.

Gatius FL, Urgel JC. 1989. Reproductive parameters in dairy cows with normal puerperium treated with prostaglandin F2a-Tham on day 14 postpartum. Journal Reproduction in Domestic Animal. 24: 201-206.

Gwazdauskas FC. 1985. Effects of climate on reproduction in cattle. Journal Dairy Science. 68: 1568-1578.

Hafez ESE, HafezB. 2000. Reproduction in farm animals. $7^{\text {th }}$ edition. Philadelphia (US): Lea and Febiger. p405-430.

Hassan M, Husnain A, Naveed MI, Riaz U, Ahmad N. 2016. Effect of ovsynch versus prostaglandin $\mathrm{F} 2 a$ protocol on estrus response, ovulation rate, timing of ovulation and pregnancy per artificial insemination in Sahiwal cows. Journal Animal Science. 88: 445-450.

Farraz Junior MVC, Pires AV, Biehl MV, Santos MH, Polizel DM, Nepomuceno DD, Sartori R, Filho JBB,
Gonçalves JRS, Day ML. 2016. Luteolysis in Bosindicus cows on days 5 and 7 of estrous cycle with varying doses of $\mathrm{PGF}_{2 a}$. Theriogenology. 86(5): 1268-1274.

Kumar A, Mehrotra S, Dangi SS, Singh G, Singh M, Mahla AS. 2012. Amylase activity in cerical mucus and serum during estrus in normal and repeat breeder cattle. Veterinary World. 5: 486-488.

Larson JE, Lamb GC, Stevenson JS, Johnson SK, Geary TW, Kesler DJ, Dejarnette JM, Schrick FN, DiCoztanzo A, and Arseneau JD. 2006. Synchronization of estrus in suckled beef cows for detected estrous and artificial insemination using gonadotroping-releasing hormone, prostaglandin $F_{2 a}$, and progesteron. Journal Animal Science. 84: 332-342.

Lauderdale JW. 2006. History, efficacy and utilization of prostaglandin F2 alpha for estrous synchronization. Proceeding of Applied Reproductive Strategies in Beef Cattle, St Joseph, Missouri. p33-48.

Layek SS, Mohanty TK, Kumaresan A, Behera K, Chand S. 2013. Cervical mucus characteristics and periestrual hormone concentration in relation to ovulation time in Zebu (Sahiwal) cattle. Journal Live Science. 152: 273-281.

Lemaster JW, Yelich JV, Kempfer JR, Fullenwider JK, Barnett CL, Fanning M, and Selph JF. 2001. Effectiveness of $\mathrm{GnRH}$ plus prostaglandin F2 $\alpha$ for estrus synchronization in cattle of Bos indicus breeding. Journal Animal Science. 79:309-316.

Lewis GS, Aizinbud E, Lehrer AR. 1989. Changes in electrical resistance of vulvar tissue in Holstein cows during ovarian cycles and after treatment with prostaglandin F2a. Journal Animal Reproduction Science. 18: 183-197.

Martins JPN, Policelli RK, Neuder LM, Raphael W, Pursley JR. 2011. Effects of cloprostenol sodium at final prostaglandin $F_{2 a}$ of Ovsynch on complete luteolysis and pregnancy per artificial insemination in lactating dairy cows. Journal Dairy Science. 94: 2815-2824.

Nascimento $A B$, Souza $A H$, Keskin A, Sartori R, Wiltbank MC. 2014. Lack of complete regression of the Day 5 corpus luteum after one or two doses of $\mathrm{PGF}_{2 a}$ in nonlactating Holstein cows. Theriogenology. 81: 389-395.

Patil SR, Pawshe CH. 2011. Vaginal electrical resistance during different phase of estrus cycle in cows and heifers. Indian Journal of Animal Reproduction. 32: 58-60.

Plata NI, Spitzer JC, Henricks DM, Thompson CE, Plyler BB, Newby TJ. 1989. Endocrine, estrous 
and pregnancy response to varying dosages of luprostiol in beef cows. Theriogenology. 31: 801812.

Rezac P, Krivanek I, Poschel M. 2001. Changes of vaginal and vestibular impedance in dairy goats during the estrous cycle. JournalSmall Ruminant Research. 42: 185-190.

Ribeiro ES, Bisinotto RS, Favoreto MG, Martins LT, Cerri RLA, Silvestre FT, Greco LF, Thatcher WW, Santos JEP. 2012. Fertility in dairy cows following presynchronization and administering twice the luteolytic dose of prostaglandin $\mathrm{F} 2 \mathrm{a}$ as one or two injections in the 5-day timed artificial insemination protocol. Theriogenology. 78 (2): 273-284.

Rodtian P, King G, Subrod S, Pongpiachan P. 1996. Oestrous behaviour of Holstein cows during cooler and hotter tropical seasons. Journal Animal Reproduction Science. 45: 47-58.

Salverson R, Perry G. 2007. Understanding estrus synchronization of cattle. South Dakota State University-Cooperative Extansion Service-USDA. p1-6.

Schindler D, Lewis GS, Rosenberg M, Tadmor A, Ezov N, Ron M, Aizinbud E, Lehrer AR. 1990. Vulvar electrical impedance in periparturient cows and its relation to plasma progesterone, oestradiol-17 $\beta$ and PGFM. Journal Animal Reproduction Science. 23: 283-292.

Setiadi MA, Aepul. 2010. Daya penghambatan arus listrik daerah vagina pada domba setelah sinkronisasi estrus. Prosiding Seminar Nasional Peranan Teknologi Reproduksi Hewan dalam Rangka Swasembada Pangan Nasional. p135-138.

Setiadi MA, Setiawan KD, Yunitasari ED. 2014. Response and characteristics of estrous of etawa grade goats after different routes of prostaglandin application. Procedings The $2^{\text {nd }}$ AsianAustralasian Dairy Goats Conference. p135-138.

Stephen LA, Rajamahendran R. 1998. A comparison of two estrus synchronization methods in beef heifers. Journal Animal Science. 78:437-438.

Stevenson JS, Phatak AP. 2010. Rates of luteolysis and pregnancy in dairy cows after treatment with cloprostenol or dinoprost. Theriogenology. 73: 1127-1138.
Stotzel C, Plöntzke J, Heuwieser W, Roblitz S. 2012. Advances in modeling of the bovine estrous cycle: Synchronization with PGF2a. Journal Dairy Science. 78: 1415-1428.

Torres XV, Morales PL, Arango JC. 2013. The effect of dose and type of cloprostenol on the luteolytic response of dairy cattle during the ovsynch protocol under different oestrous cycle and physiological characteristics. Journal Reproduction in Domestic Animal. 48: 874-880.

Tsiligianni T, Karagiannidis A, Brikas P, Saratsis P. 2000. Physical properties of bovine cervical mucus during normal and induced (Progesterone and/or $\mathrm{PGF}_{2 \mathrm{a}}$ ) estrus. Theriogenology. 55: 629640.

Uslenghi G, Vater A, Aguilar SR, Cabodevila J, Callejas S. 2016. Effect of estradiol cypionate and $\mathrm{GnRH}$ treatment on plasma estradiol-17 $\beta$ concentrations, synchronization of ovulation and on pregnancy rates in suckled beef cows treated with FTAI-based protocols. Journal Reproduction in Domestic Animal. 51: 693-699.

Verma KK, Prasad S, Kumaresan A, Mohanty TK, Layek SS, Patbandha TK, Chand S. 2014. Characterization of physico-chemical properties of cervical mucus in relation to parity and conception rate in Murrah buffaloes. Veterinary World. 7: 467-471.

Waldmann A, Kurykin J, Jaakma U, Kaart T, Aidnik M, Jalakas M, Majas L, Padrik P. 2006. The effects of ovarian function on estrus synchronization with PGF in dairy cows. Journal Dairy Science. 66: 1364-1374.

Whitley NC, Jackson DJ. 2004. An update on estrus synchronization in goats: A minor species. Journal Animal Science. 82: E270-E276.

Yoshida C, Yusuf M, Nakao T. 2009. Duration of estrus induced after $\mathrm{GnRH}_{-} \mathrm{PGF}_{2 \alpha}$ protocol in dairy heifer. Journal Animal Science. 80: 649-654.

Zaaijer D, Counotte GHM, Sol J,Smidt WJ, Broadbent PJ. 1992. Changes in the composition of cervical mucus of the cow during the estrous cycle as parametersfor predicting potential fertility. Theriogenology. 39:569-580. 